Jakub GRABOWSKI

ASM - Centrum Badań i Analiz Rynku w Kutnie

Andrzej STASIAK

Uniwersytet Łódzki

\title{
RUCH TURYSTYCZNY NA TERENIE NADWIŚLAŃSKIEGO POGRANICZA MAZOWIECKO-KUJAWSKIEGO
}

\section{Wstęp}

W 2011 r. Lokalna Grupa Działania Fundacji „Aktywni Razem” zwróciła się do Wyższej Szkoły Turystyki i Hotelarstwa w Łodzi z prośbą o przeprowadzenie badań ruchu turystycznego na terenie jej działalności. Obszar ten w dokumentach programowych Fundacji określany jest mianem Nadwiślańskiego Pogranicza Mazowiecko-Kujawskiego.

Za ruch turystyczny powszechnie uznaje się „ogół przestrzennych przemieszczeń się ludzi związanych z dobrowolną czasową zmianą miejsca pobytu, środowisk i rytmu życia - w odniesieniu do określonego obszaru, kierunku, okresu itp." (Definicje podstawowych pojęć... 1979). W podróżach tych biorą udział zarówno turyści (spędzający przynajmniej jedną noc w bazie noclegowej obszaru), jak i odwiedzający jednodniowi, zwani też po polsku wycieczkowiczami (przebywający na obszarze bez noclegu). Badanie miało więc polegać na identyfikacji struktury przyjeżdżających na teren 
Nadwiślańskiego Pogranicza Mazowiecko-Kujawskiego oraz wszechstronnej (demograficzno-społeczno-ekonomicznej) charakterystyce tych migracji.

Zadanie okazało się niezwykle interesujące zarówno z poznawczego, jak i praktycznego punktu widzenia. Już sam obszar - choć sztucznie wyodrębniony - jest bardzo ciekawy. Mimo położenia w centralnej Polsce, znajduje się na peryferiach administracyjnych (na styku granic trzech województw), a także z dala od głównych regionów i ośrodków turystycznych kraju. Obejmuje wprawdzie Pojezierze Gostynińskie - „stary” rejon wypoczynkowy przyciągający turystów od co najmniej pół wieku, ale w ostatnim czasie jakby trochę zapomniany. Lekarstwem na stagnację ma być wielka inwestycja geotermalna. Powstanie term gostynińskich z pewnością przyczyni się do odnowy turystyki na tym terenie. $Z$ wielu jednak powodów rozpoczęcie tego ambitnego przedsięwzięcia opóźnia się.

Badania ruchu turystycznego zrealizowane zostały więc $\mathrm{u}$ progu wielkich, wręcz rewolucyjnych, zmian. Dzięki temu możliwe stało się określenie podstawowych cech „starej”, prawdopodobnie kończącej się już, turystyki. Co ciekawe, badania miały charakter pionierski, gdyż mimo długich tradycji turystycznych nie prowadzono wcześniej na tym obszarze badań ankietowych turystów (przynajmniej na tak dużą skalę). Uzyskane wyniki mają więc też istotne znaczenie utylitarne - dostarczają informacji niezbędnych do strategicznego zarządzania rozwojem turystyki na Pojezierzu Gostynińskim.

\section{Charakterystyka obszaru ${ }^{1}$}

Obszar badań obejmował 11 gmin z województwa mazowieckiego i kujawsko-pomorskiego zrzeszonych w ramach LGD Fundacji „Aktywni Razem”. W większości są to gminy o charakterze wiejskim, zamieszkiwane przez ponad 66 tys. osób. Łącznie zajmują powierzchnię 1327,09 km² (rys. 1). Pod względem geograficznym wyznaczony obszar jest bardzo zróżnicowany. Według regionalizacji J. KONDRACKIEGO (2002) leży bowiem na granicy dwóch podprowincji: Pojezierzy Południowobałtyckich i Nizin Środkowopolskich. Pierwszą z nich reprezentują fragmenty dwóch makroregionów: Pradolina Toruńsko-Eberswaldzka (mezoregion Kotlina Płocka) i Nizina Środkowoma-

\footnotetext{
${ }^{1}$ Dane liczbowe w tym rozdziale, o ile nie zaznaczono inaczej, pochodzą z Lokalnej strategii rozwoju Nadwiślańskiego Pogranicza Mazowiecko-Kujawskiego (2008).
} 
zowiecka (skrajny zachodni mezoregion Równina Kutnowska), drugą zaś kolejne dwa makroregiony: fragmenty Pojezierza Wielkopolskiego (najbardziej na południowy wschód wysunięty mezoregion Pojezierze Kujawskie), a także północny skrawek Niziny Południowowielkopolskiej (mezoregion Wysoczyzna Kłodawska). Ich granice zbiegają się w okolicach Gostynina.

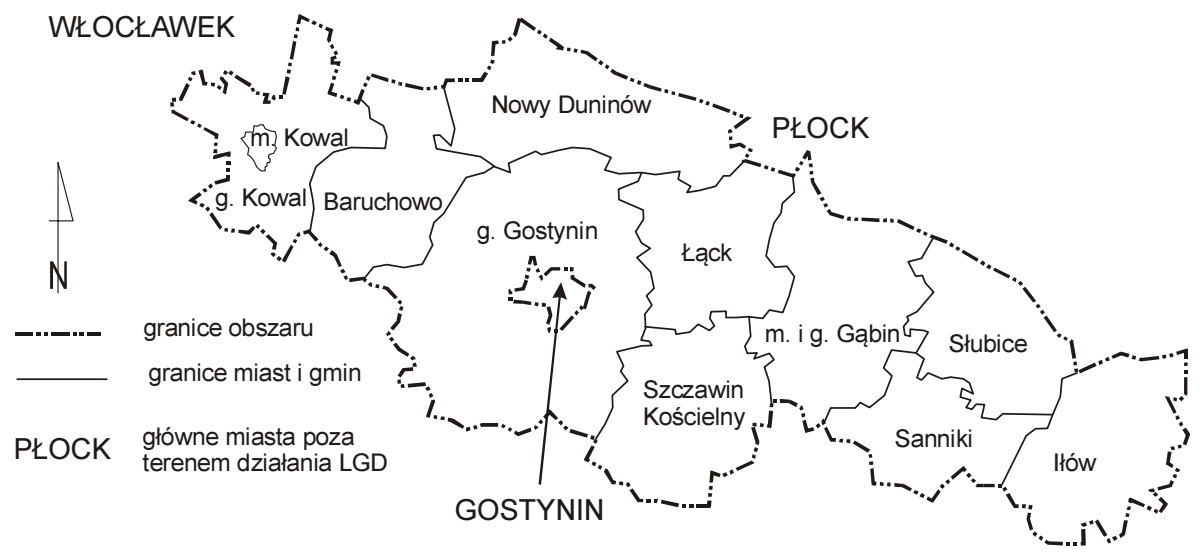

Rys. 1. Gminy należące do LGD Fundacja „Aktywni Razem” Źródło: opracowanie własne

Graniczny charakter obszaru podkreśla także jego duże zróżnicowanie krajobrazowe. Tereny na północy (ok. ${ }^{2} / 3$ obszaru) położone są $\mathrm{w}$ pradolinie Wisły. Rozległe terasy zalewowe o powierzchni około $150 \mathrm{~km}^{2}$ (w gminach Łąck, Gąbin, Słubice i Iłów) obecnie odcięte są od rzeki wałami. Na wysokiej terasie pradoliny do dziś zachowały się formy związane $\mathrm{z}$ zanikiem jeziora lodowcowego. Bardziej na południe występuje już typowy krajobraz młodoglacjalny: 63 malownicze jeziora (zarówno rynnowe, jak i wytopiskowe), ozy i kemy, a także częściowo przemodelowane przez wiatr wały wydmowe (holoceńskie wydmy piaskowe) oraz mokradła i niewielkie torfowiska w zagłębieniach terenu. Najbardziej znaną formą geomorfologiczna, a zarazem dużą atrakcją turystyczną jest tzw. Oz Gostyniński - kręty wał towarzyszący dolinie Skrwy, o długości 14 km i maksymalnej wysokości 121,5 m n.p.m. (Dybanka). Obszar o typowym krajobrazie pojeziernym potocznie nazywany jest Pojezierzem Gostynińskim, niekiedy wyróżnia się też Pojezierze Łąckie i Pojezierze Gostynińskie. W naukowych regionalizacjach nazwy takich krain jednak nie występują. 
Najbardziej monotonny krajobraz ma południowo-wschodnia część obszaru. Gminy Szczawin Kościelny, Sanniki, Słubice, Iłów i częściowo Gąbin nie zostały objęte zasięgiem oddziaływania ostatniego zlodowacenia. Stąd generalnie dość płaskie ukształtowanie terenu i małe urozmaicenie pod względem siedliskowym.

Cały badany obszar charakteryzuje się jednak dość znaczną bioróżnorodnością. Przejawia się to m.in. w dużym odsetku lasów. Lesistość regionu (29\%) jest co prawda nieznacznie wyższa od średniej krajowej, ale wyraźnie przewyższa lesistość województw mazowieckiego (22,3\%) i kujawsko-pomorskiego (23,2\%). Wśród 15 wyróżnionych typów siedliskowych zdecydowanie dominują bory mieszane i świeże, tworzące około $70 \%$ kompleksów leśnych.

Ponad $2 / 3$ powierzchni obszaru zajmują obszarowe formy ochrony przyrody. Są to:

- utworzony w 1979 r. Gostynińsko-Włocławski Park Krajobrazowy jego powierzchnia wynosi niemal 40 tys. ha, z czego 60\% stanowią lasy, głównie bory sosnowe i bory mieszane. Tworzą one naturalny korytarz ekologiczny łączący Puszczę Kampinoską z Puszczą Bydgoską i Borami Tucholskimi. Występuje tu blisko 800 gatunków roślin naczyniowych (52 gatunki objęte ochroną prawną) oraz około 150 gatunków ptaków (m.in. bocian czarny, kulik wielki, żuraw, batalion, sieweczka obrożna, wąsatka, bąk);

- dwa Obszary Specjalnej Ochrony Ptaków, funkcjonujące w ramach sieci Natura 2000: Błota Rakutowskie (3 tys. ha) oraz Dolina Środkowej Wisły ( 2,1 tys. ha) i chroniące 23 cenne, zagrożone gatunki ptaków lęgowych i migrujących;

- 20 rezerwatów przyrody o łącznej powierzchni około 2500 ha.

Oprócz wymienionych walorów przyrodniczych badany region dysponuje cennymi walorami antropogenicznymi zarówno o charakterze materialnym, jak i duchowym. Do najważniejszych zabytków należy zaliczyć: zamek w Gostyninie (z XIV w., odbudowany na początku XXI w.), XIX-wieczne dwory i pałace, w tym związany z F. Chopinem pałac w Sannikach oraz pałac w Łącku (letnia siedziba marsz. E. Rydza-Śmigłego) wraz ze Stadem Ogierów, liczne wiejskie drewniane i murowane kościoły z XIX i XX w., stanowiska archeologiczne w okolicach wsi Szczawin Kościelny (m.in. z przełomu paleolitu i mezolitu, kultury pucharów lejkowych, kultury łużyckiej i przeworskiej), pozostałości masztu radiowego w Konstantynowie k. Gą- 
bina (do 1991 r. najwyższej konstrukcji na świecie - 646 m wysokości), a także układy urbanistyczne małych miasteczek (Gostynin, Gąbin, Kowal). Wśród głównych walorów niematerialnych można wymienić: folklor pogranicza Kujaw i Mazowsza (Białych Kujaw i ziemi gąbińsko-sannickiej), miejsca związane z ostatnimi królami z dynastii Piastów: Władysławem Łokietkiem i Kazimierzem Wielkim (ur. w Kowalu), dziedzictwo olendrów, pracujących nad melioracją doliny Wisły, miejsca pobytu przedstawicieli obozu piłsudczyków (m.in. marsz. E. Rydza-Śmigłego, ostatniego premiera II RP F.S. Składkowskiego), koncerty chopinowskie w Sannikach, historię i pozostałości kultury mniejszości niemieckiej i żydowskiej (sprzed II wojny światowej).

Wyjątkowe w skali środkowej Polski walory przyrodnicze, interesujące walory kulturowe, a także dogodna lokalizacja w stosunku do dużych skupisk miejskich (ok. $80-120 \mathrm{~km}$ od aglomeracji warszawskiej, $60-80 \mathrm{~km}$ od aglomeracji łódzkiej, sąsiedztwo dwóch ośrodków o znaczeniu regionalnym: Włocławka i Płocka) sprawiły, że Pojezierze Gostynińskie wzbudziło zainteresowanie turystów już w latach 60. i 70. XX w. Nad najpiękniejszymi jeziorami (m.in. Białym, Lucieńskim, Sumino) powstały wtedy pierwsze zakładowe ośrodki wypoczynkowe. Najbardziej znany spośród nich jest Ośrodek Kancelarii Prezydenta RP w Lucieniu². Typową nadwodną bazę wypoczynkową uzupełniają obiekty o niższym standardzie: kempingi, pola namiotowe oraz stanice wodne. W przeszłości podczas wakacji wiejskie szkoły zamieniane były na schroniska młodzieżowe. Obecnie w dwóch wygaszonych placówkach funkcjonują całoroczne "zielone szkoły" (Modelowe Wiejskie Centrum Ekoturystyki w Sendeniu Małym, "Zielona Szkoła” w Goreniu Dużym). W 2. połowie lat 90. XX w. na badanym obszarze pojawiły się pierwsze gospodarstwa agroturystyczne. Przyjmowanie turystów w funkcjonujących gospodarstwach rolnych staje się coraz bardziej popularne, a ich liczba sukcesywnie rośnie. Przeprowadzona przed rozpoczęciem badań terenowych w 2011 r. inwentaryzacja bazy noclegowej Nadwiślańskiego Pogranicza Mazowiecko-Kujawskiego wykazała: 69 gospodarstw agroturystycznych, 20 ośrodków wypoczynkowych, sześć małych hoteli, cztery stanice wodne oraz pojedyncze nieskategoryzowane obiekty określane mianem: pensjonat, hotelik, motel, motelik, zajazd.

\footnotetext{
${ }^{2}$ Kancelaria Prezydenta RP zarządza obiektem od 1989 r., wcześniej był to ośrodek Rady Państwa, potocznie nazwany przez mieszkańców „ochabówką".
} 
W Lokalnej strategii rozwoju... (2008) zawarto krótką charakterystykę turystyki w regionie na początku XXI w. Wynika z niej, że:

[...] profil społeczny turystów odwiedzających region jest dość zróżnicowany, przy czym dominują osoby raczej mniej zamożne, w tym pary $\mathrm{w}$ wieku przedemerytalnym lub emerytalnym, rodziny $\mathrm{z}$ dziećmi oraz młodzież szkolna. Turyści o wyższym statusie materialnym to m.in. turyści kulturowi z zagranicy oraz biznesmeni ze stolicy (turystyka konferencyjna), a także pewna część właścicieli działek letniskowych. Podstawowym celem przyjazdów jest spokojny wypoczynek, powiązany z korzystaniem z najbardziej oczywistych atrakcji naturalnych (spacery po lesie, ryby, kąpiel w jeziorach) i prostych atrakcji „,sztucznych” (grill, mała gastronomia, przejażdżka bryczką) ${ }^{3}$.

Podkreślono też, że w ostatnich latach wyraźnie rozwinęły się niektóre formy turystyki kwalifikowanej (żeglarstwo, turystyka rowerowa i konna) i ekoturystyki (bird watching, turystyka edukacyjna w ,zielonych szkołach"), a także agroturystyka. Zdecydowana większość turystów pochodziła z Polski (dominowali goście z okolic Warszawy i Łodzi, na dalszych miejscach znalazł się Śląsk i Kraków oraz pobliskie duże miasta: Płock i Włocławek). Nieliczni turyści zagraniczni przyjeżdżali głównie do pałacu w Sannikach (podróże śladami F. Chopina).

Wspomniany dokument zawiera również szczegółową analizę sytuacji gospodarczej regionu. Wynika z niej, że w latach 1996-2002:

- ogólna liczba miejsc pracy zmniejszyła się o około 500;

- znacząco zmieniła się struktura gospodarki: zmalała rola większych zakładów pracy (spadek udziału w zatrudnieniu z 24\% do 19\%) i gospodarstw indywidualnych (z 63\% do 56\%), niemal dwukrotnie wzrosło znaczenie mikrofirm (z 13\% do 25\%);

- warunki produkcji rolniczej są generalnie niekorzystne z powodu bardzo dużego udziału najsłabszych gleb i rosnącego deficytu wody;

- wobec ograniczeń rozwoju przemysłu (obszary prawnie chronione) szansą dla regionu może być turystyka, odgrywająca jednak na razie stosunkowo niewielką rolę - oszacowano, że sektor ten w skali roku daje pracę około 400-500 osobom.

${ }^{3}$ Autorzy opracowania nie wskazują jednak źródła podawanych informacji. Najprawdopodobniej jest to charakterystyka turystów oparta jedynie na opiniach i obserwacjach przedstawicieli lokalnej branży turystycznej. 


\section{Plany rozwoju turystyki}

Możliwość wykorzystania turystyki jako swoistego koła zamachowego dla całej lokalnej gospodarki dostrzeżono zresztą już na początku XXI w. W przyjętym w 2004 r. Planie rozwoju lokalnego miasta Gostynin, a także późniejszym Programie aktywizacji gospodarczej miasta Gostynina w oparciu o jego zasoby jednoznacznie wskazano na konieczność wykorzystania złóż wód geotermalnych w zakresie balneologicznym i ciepłowniczym. Głównym celem inwestycyjnym miało być stworzenie Ponadregionalnego Centrum Turystyki, Balneologii, Wypoczynku i Rekreacji.

Według Wstępnego studium wykonalności z 2009 r. przedsięwzięcie miało mieć rangę ogólnopolską a nawet międzynarodową (m.in. miało konkurować z podobnymi obiektami na Słowacji i na Węgrzech). Planowano zagospodarowanie obszaru o powierzchni 17 ha, w tym m.in. budowę parku wodnego wraz z kąpieliskiem zewnętrznym (o łącznej powierzchni $6684 \mathrm{~m}^{2}$ ) z 11 basenami, SPA $\left(3670 \mathrm{~m}^{2}\right)$ z sześcioma basenami, częścią leczniczą, terapeutyczną i balneologiczną $\left(1766 \mathrm{~m}^{2}\right)$, centrum konferencyjnego $\left(2607 \mathrm{~m}^{2}\right)$, lodowiska $\left(1800 \mathrm{~m}^{2}\right)$, 4-gwiazdkowego hotelu z 400 miejscami noclegowymi wraz z restauracją $\left(8660 \mathrm{~m}^{2}\right)$, terenów zielonych $\left(23000 \mathrm{~m}^{2}\right)$, kortów tenisowych, minigolfa, boisk sportowych i placów zabaw $\left(5388 \mathrm{~m}^{2}\right)$. Zakładano, że z basenów geotermalnych będzie korzystać 860 tys. osób rocznie, a liczba sprzedanych noclegów wyniesie 43,8 tys. rocznie. Realizacja projektu miała przynieść zatrudnienie dla około 230 osób bezpośrednio w obiekcie oraz blisko 1 tys. osób $\mathrm{w}$ firmach świadczących usługi na rzecz kompleksu4. Dodatkową korzyścią miało być pobudzenie działalności gospodarczej na terenie Gostynina oraz rozwój usług turystycznych (w tym zwłaszcza agroturystyki) w promieniu 20-25 km od miasta.

Projekt początkowo spotkał się z dużym zainteresowaniem i szerokim poparciem lokalnej społeczności, która wiązała z nim duże nadzieje na diametralną odmianę sytuacji gospodarczej regionu. Wraz z pojawiającymi się problemami i kilkakrotnie przesuwanym terminem rozpoczęcia inwestycji, entuzjazm zastąpiło zniechęcenie i apatia.

${ }^{4}$ Założenia te nie były jednak poparte jakimikolwiek analizami rynku i szybko okazało się, że są zupełnie nierealne. W 2012 r. na zlecenie miasta opracowano nowe Studium woykonalności projektu Centralny Park Rekreacji, Balneologii, Turystyki i Wypoczynku Termy Gostynińskie, w którym urealniono niektóre wskaźniki, m.in. zmniejszono przewidywaną liczbę nowych etatów do 112, a liczbę turystów do 600 tys. rocznie. 
Przyczyn braku realizacji przedsięwzięcia jest oczywiście wiele. Do najważniejszych należy jednak zaliczyć: trudności z pozyskaniem inwestora (m.in. odwołanie pierwszego postępowania o koncesje na roboty budowlane), nieprzyznanie przez Zarząd Województwa Mazowieckiego dotacji unijnych (przeniesienie projektu na listę rezerwową Wykazu Indywidualnych Projektów Kluczowych dla RPO WM 2007-13), stwierdzenie wysokiego poziomu wód gruntowych, który istotnie zwiększył skalę trudności i koszty projektu, a także formalnoprawne i finansowe nieprawidłowości przy projektowaniu przedsięwzięcia i realizacji partnerstwa publiczno-prywatnego ${ }^{5}$. W efekcie budowa kompleksu term gostynińskich utknęła na lata, a ich powstanie nawet $\mathrm{w}$ dalszej perspektywie stanęło pod dużym znakiem zapytania.

\section{Metody i realizacja badań ruchu turystycznego}

Głównym celem badań była identyfikacja podstawowych cech ruchu turystycznego kierującego się w 2011 r. na Nadwiślańskie Pogranicze Mazowiecko-Kujawskie, a zwłaszcza takich jego parametrów, jak:

- wielkość i sezonowość;

- struktura społeczna turystów;

- preferencje turystów w zakresie: realizacji celów turystycznych, długości i sposobu organizacji pobytu, wyboru miejsc wypoczynku, atrakcji turystycznych oraz obiektów infrastruktury turystycznej.

Realizacja tak sformułowanego celu wymagała wykorzystania całego zestawu metod badawczych służących określeniu zarówno jakościowych, jak i ilościowych cech ruchu turystycznego. W niniejszym opracowaniu zostaną zaprezentowane jedynie wyniki wywiadów kwestionariuszowych z turystami, inwentaryzacji numerów rejestracyjnych samochodów w miejscach prowadzenia badań, a także ankiet wypełnianych przez gestorów bazy noclegowej.

${ }^{5}$ Przeprowadzona w 2012 r. kontrola NIK wykazała m.in. brak identyfikacji, oceny i alokacji ryzyk związanych z przedsięwzięciem, uchybienia w ogłoszeniu kryteriów oceny ofert, nienależyte zabezpieczenie interesów miasta, brak działań zmierzających do wyegzekwowania od koncesjonariusza zobowiązań, brak opracowania wewnętrznych procedur postępowania przy realizacji PPP. NIK zarzucił władzom miasta niegospodarność przy wydatkowaniu ponad 7,6 mln zł na dokumentację budowlaną. 
Ważną kwestią w procesie planowania badań było ustalenie liczby turystów, z którymi powinny zostać przeprowadzone wywiady. Kryterium pozwalającym na dokonanie cechującego się obiektywnością podziału był poziom rozwoju funkcji turystycznej poszczególnych gmin w 2010 r. Do jego oszacowania wykorzystane zostały wielkości zaczerpnięte z Banku Danych Lokalnych GUS: liczba miejsc noclegowych, liczba osób korzystających z obiektów rejestrowanej bazy noclegowej, liczba przedsiębiorstw zarejestrowanych w sekcji "I"6 oraz ", $\mathrm{R}^{\prime \prime}$ według PKD 2007. Na podstawie udziału procentowego poszczególnych gmin w całkowitej funkcji turystycznej regionu ustalono proporcjonalnie minimalną liczbę turystów mających zostać objętych badaniem ankietowym na ich terenie.

Po konsultacji z instytucją zlecającą badanie wybranych zostało 12 ogólnodostępnych miejsc, w których w określonych dniach od lipca do września 2011 r. przeprowadzono wywiady z turystami. Badania zrealizowano bez większych kłopotów. Jedyny problem stanowiła niestabilna pogoda, co przekładało się na istotne wahania liczby wypoczywających turystów. Ogółem uzyskano ponad 700 ankiet. Po zweryfikowaniu do dalszej analizy zakwalifikowano 690 kwestionariuszy.

Oprócz przeprowadzania wywiadów z turystami ankieterzy prowadzili też obserwację samochodów parkujących na wyznaczonych parkingach. Ogółem zidentyfikowano i zanotowano 1355 numerów tablic rejestracyjnych pojazdów.

W przypadku ankiety skierowanej do właścicieli obiektów bazy noclegowej uzyskano zwrot 13 formularzy, w tym jednego z hotelu ("Dębowa Góra" w Nowych Rumunkach), jednego ze schroniska młodzieżowego (SSM Zielona Szkoła w Sendeniu Małym) oraz 11 z gospodarstw agroturystycznych. W formularzach często brakowało danych statystycznych dotyczących wielkości ruchu turystycznego, druga część ankiety dostarczyła jednak wielu ciekawych spostrzeżeń na temat obserwowanych w regionie trendów i zjawisk w ruchu turystycznym.

\footnotetext{
${ }^{6}$ Działalność związana z zakwaterowaniem i usługami gastronomicznymi.

${ }^{7}$ Działalność związana z kultura, rozrywką i rekreacją.
} 


\section{Wyniki badań}

\subsection{Wielkość i sezonowość ruchu turystycznego}

Wobec braku możliwości prowadzenia badań na szeroką skalę oraz niepełnych danych statystycznych dotyczących liczby udzielonych noclegów dokładne oszacowanie globalnej wielkości ruchu turystycznego na terenie Nadwiślańskiego Pogranicza Mazowiecko-Kujawskiego okazało się niemożliwe. Uzyskane informacje o ruchu turystycznym w bazie noclegowej regionu w latach 2008-2010 pozwalają jednak na uchwycenie kilku tendencji.

Funkcjonujące na terenie Pojezierza Gostynińskiego obiekty hotelarskie są bardzo zróżnicowane pod względem rodzaju i standardu. Istnieją tu zarówno hotele, ośrodki wypoczynkowe, schroniska młodzieżowe, jak i gospodarstwa agroturystyczne. Dlatego też liczba turystów nocujących w 2010 r. w 13 obiektach, które wypełniły ankietę była diametralnie różna (tab. 1). Najwięcej gości przyjął hotel „Dębowa Góra” w Nowych Rumunkach (ponad 6,7 tys.). Drugie pod względem frekwencji okazało się schronisko młodzieżowe w Sendeniu Małym (ponad 1,2 tys.). Z kolei trzy gospodarstwa agroturystyczne nie podały w ogóle liczby turystów (otwarte pozostaje pytanie: czy w ostatnich latach nie miały ani jednego gościa, czy też nie chciały podzielić się tymi informacjami?). Ogółem badane obiekty w 2010 r. udzieliły gościny ponad 8,5 tys. turystów.

Bardzo podobnie wygląda struktura udzielonych noclegów. W tej kategorii również prym wiedzie hotel „Dębowa Góra” w Nowych Rumunkach (ponad 7,8 tys. noclegów). Za nim znalazło się schronisko młodzieżowe w Sendeniu Małym (blisko 2,7 tys. noclegów). Na trzecim miejscu uplasowało się jednak Siedlisko „Pod Lipą” w Budach Lucieńskich (762 noclegi). Dowodzi to zdecydowanie dłuższych pobytów turystów w tym obiekcie. Ogółem w 2010 r. udzielono ponad 12 tys. noclegów.

Ważniejsza od identyfikacji wielkości frekwencji w 2010 r. jest analiza trendu w latach 2008-2010. Niestety, wnioski nie są optymistyczne. W większości obiektów odnotowano wyraźny spadek zarówno liczby turystów, jak i liczby udzielonych noclegów.

Ruch turystyczny na terenie Nadwiślańskiego Pogranicza MazowieckoKujawskiego charakteryzuje się wysoką sezonowością. Zdecydowana większość respondentów (ponad 80\%), zapytana o porę roku, w której wypo- 
czywa na Pojezierzu Gostynińskim, wskazała lato. Pozostałe trzy pory roku wymieniło tylko po kilka procent ankietowanych.

Tabela 1. Ruch turystyczny w obiektach noclegowych Nadwiślańskiego Pogranicza Mazowiecko-Kujawskiego w latach 2008-2010

\begin{tabular}{|c|c|c|c|}
\hline \multirow{2}{*}{ Liczba turystów } & \multicolumn{3}{|c|}{ Rok } \\
\hline & 2008 & 2009 & 2010 \\
\hline Hotel „,Dębowa Góra”/Nowe Rumunki & 7158 & 6320 & 6713 \\
\hline SSM-Zielona Szkoła/Sendeń Mały & 1594 & 1663 & 1243 \\
\hline Osada Dębowo & 120 & 200 & 280 \\
\hline Siedlisko „Pod Lipą"Budy Lucieńskie & 168 & 192 & 138 \\
\hline Zdwórz & 120 & 102 & 95 \\
\hline Gospodarstwo agroturystyczne/Koszelówka & 67 & 78 & 52 \\
\hline Agroturystyka LEWMAR/Huta Nowa & - & - & 37 \\
\hline "Zacisze" & - & - & 24 \\
\hline Gospodarstwo agroturystyczne/Wólka Niska & 24 & 26 & 22 \\
\hline Gospodarstwo agroturystyczne/Sierakówek & 17 & 12 & 18 \\
\hline Razem & 9268 & 8593 & 8622 \\
\hline \multirow{2}{*}{ Liczba udzielonych noclegów } & \multicolumn{3}{|c|}{ Rok } \\
\hline & 2008 & 2009 & 2010 \\
\hline Hotel „Dębowa Góra”/Nowe Rumunki & 11223 & 10145 & 7826 \\
\hline SSM-Zielona Szkoła/Sendeń Mały & 3221 & 2764 & 2674 \\
\hline Siedlisko „Pod Lipą”/Budy Lucieńskie & 748 & 892 & 762 \\
\hline Osada Dębowo & 120 & 200 & 280 \\
\hline Zdwórz & 200 & 180 & 155 \\
\hline Gospodarstwo agroturystyczne/Wólka Niska & 52 & 79 & 97 \\
\hline "Zacisze, & - & - & 95 \\
\hline Gospodarstwo agroturystyczne/Sierakówek & 60 & 40 & 75 \\
\hline Agroturystyka LEWMAR/Huta Nowa & - & - & 74 \\
\hline Gospodarstwo agroturystyczne/Koszelówka & 67 & 78 & 52 \\
\hline Razem & 15691 & 14378 & 12090 \\
\hline
\end{tabular}

Źródło: opracowanie własne na podstawie badań ankietowych.

Wyniki badań ankietowych w pełni potwierdzają też statystyki udzielonych noclegów. Wyraźnie widoczna jest przy tym korelacja pomiędzy rodzajem i kategorią obiektu noclegowego a liczbą gości. Obiektami wybitnie sezonowymi są gospodarstwa agroturystyczne - turyści odwiedzają je głównie w sezonie letnim, od maja do września (w innych miesiącach sporadycz- 
nie pojawiają się w nich pojedyncze osoby). Natomiast im wyższy standard obiektu, tym więcej gości i choć niejednolite, to całoroczne obłożenie.

$\mathrm{W}$ celu określenia zmian natężenia ruchu turystycznego w ujęciu rocznym wzięto pod uwagę jedynie trzy obiekty całoroczne i w oparciu o zgłoszoną frekwencję wyliczono wskaźniki sezonowości ${ }^{8}$. Uzyskane wyniki prezentują rys. 2 i 3.

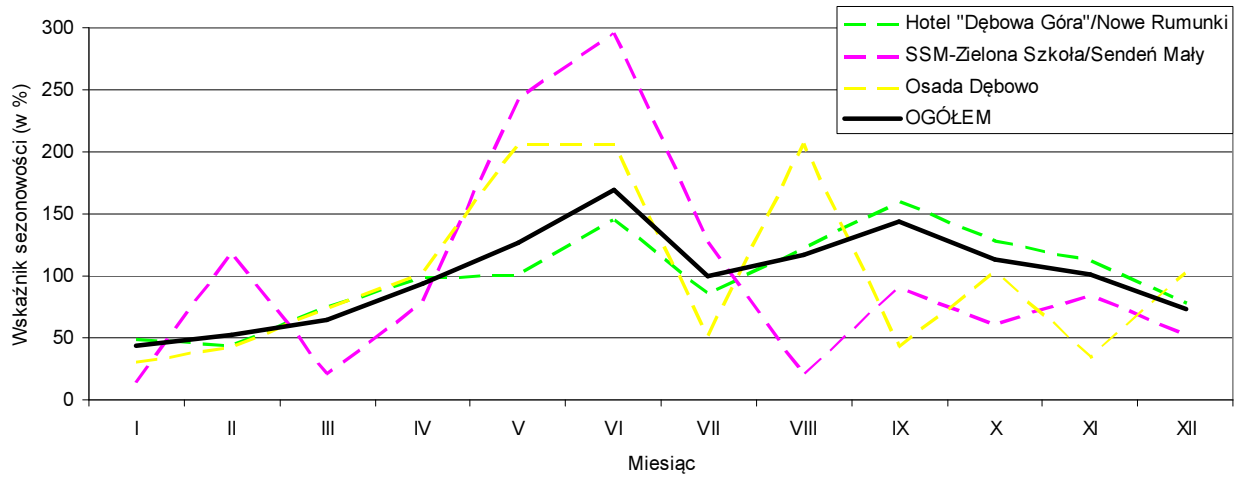

Rys. 2. Sezonowość ruchu turystycznego (wg liczby turystów) w obiektach noclegowych Nadwiślańskiego Pogranicza Mazowiecko-Kujawskiego w 2010 r.

Źródło: opracowanie własne na podstawie badań ankietowych

Na wykresie (rys. 2) wyraźnie zarysowują się dwa maksima ruchu turystycznego: w czerwcu i wrześniu, choć przez cały okres letni (od maja do września) wskaźnik sezonowości waha się w przedziale $100-170 \%$. W przypadku poszczególnych obiektów noclegowych występują jednak dość istotne różnice. W Zielonej Szkole w Sendeniu Małym maksimum ruchu przypada na maj i czerwiec, kiedy wskaźnik sezonowości osiąga niemal 300\%. Z kolei w hotelu „Dębowa Góra” największy ruch jest w czerwcu (145\%) i we wrześniu (160\%).

Trochę inaczej wygląda rozkład wskaźnika sezonowości wyliczonego na podstawie liczby noclegów (rys. 3). Zdecydowanie wyraźniej zaznacza się szczyt wakacyjny w sierpniu (hotel „Dębowa Góra” - 250\%, Osada Dębowo -

${ }^{8}$ Wskaźniki sezonowości wyliczono wg wzoru: $\mathrm{W}_{\mathrm{s}}=\mathrm{Li}_{\mathrm{i}} / \mathrm{L}_{s} \cdot 100 \%$, gdzie: $\mathrm{W}_{\mathrm{s}}$ - wskaźnik sezonowości, $\mathrm{Li}_{\mathrm{i}}$ - liczba turystów (noclegów) w danym miesiącu, Lś - średnia miesięczna liczba turystów (noclegów) $\mathrm{w}$ danym roku $(\Sigma \mathrm{Li} / 12)$. 
206\%) i gwałtowny spadek we wrześniu (poniżej 50\%). Wyjaśnienie tych różnic jest proste: $\mathrm{w}$ okresie letnim jest mniej turystów, ale ich pobyty są zdecydowanie dłuższe, jesienią zaś przybywa więcej osób, ale zatrzymują się na krócej.

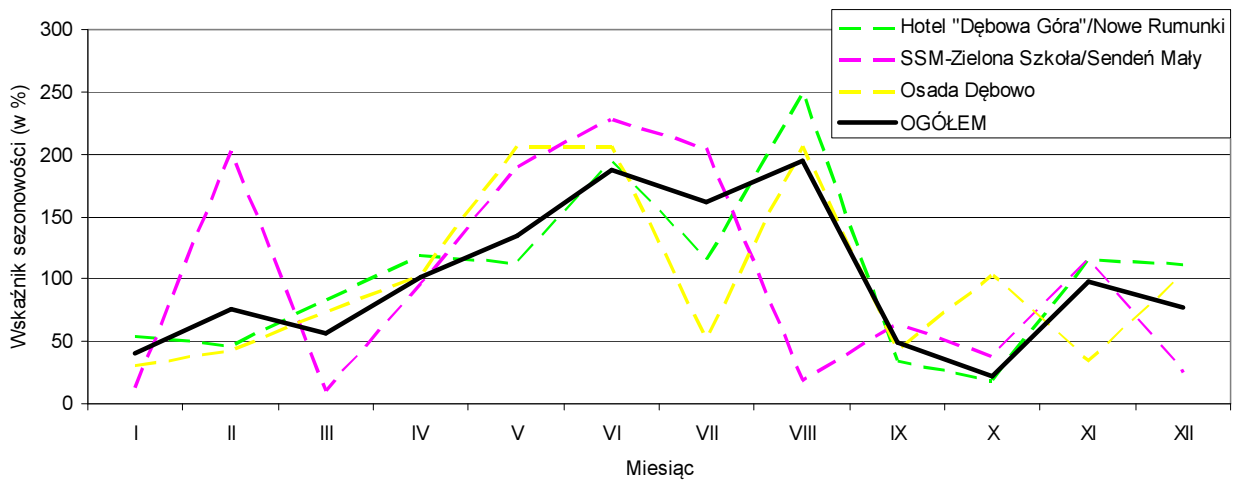

Rys. 3. Sezonowość ruchu turystycznego (wg udzielonych noclegów) w obiektach noclegowych Nadwiślańskiego Pogranicza Mazowiecko-Kujawskiego w 2010 r. Źródło: opracowanie własne na podstawie badań ankietowych

\subsection{Sylwetka turysty}

Dane pozyskane podczas badań ankietowych pozwalają na identyfikację najważniejszych cech społeczno-demograficznych turystów odwiedzających region Nadwiślańskiego Pogranicza Mazowiecko-Kujawskiego. Dzięki temu możliwe jest określenie sylwetki „przeciętnego”, statystycznego turysty wypoczywającego na tym obszarze.

Zarówno obserwacje ankieterów, jak i odpowiedzi udzielone przez respondentów dowodzą praktycznie równowagi wśród turystów pod względem płci. Kobiety i mężczyźni stanowią po około 50\% odwiedzających region. W żadnym z punktów prowadzenia badań nie odnotowano wyraźnej przewagi jednej lub drugiej płci.

Istotne dysproporcje pojawiają się natomiast w strukturze wiekowej respondentów. Tutaj wyraźnie zaznacza się dominacja ludzi młodych. Ponad $81 \%$ badanych turystów nie skończyło 40 lat, a blisko 58\% było przed „trzydziestką". Najliczniejszą grupę stanowiły osoby w przedziale 20-24 lata (co 
czwarty ankietowany). Najrzadziej zaś wśród odwiedzających Pojezierze Gostynińsko-Włocławskie pojawiają się osoby starsze: pięćdziesięcio- i sześćdziesięciolatkowie (zaledwie po kilka procent ogółu badanych).

Dość wyraźne różnice w badanej populacji zaznaczają się również pod względem wykształcenia. Zdecydowanie przeważają absolwenci szkół średnich, którzy stanowili niemal połowę (48,3\%) wszystkich ankietowanych. $\mathrm{Z}$ kolei co trzeci respondent zadeklarował wykształcenie wyższe. Do wykształcenia niższego (podstawowe, gimnazjalne, zasadnicze) przyznało się tylko po kilka procent zapytanych.

Zdecydowana większość badanych (prawie 2/3) była aktywna zawodowo. Bezrobotni stanowili jedynie 7,5\%. Co czwarty ankietowany jeszcze się uczył - czy to w szkole średniej, czy wyższej. Najmniej wśród turystów było emerytów oraz rencistów (2-3\%).

Z uwagi na dość powszechną niechęć do ujawniania swoich dochodów przez respondentów, w badaniu zastosowano metodę subiektywnej oceny sytuacji ekonomicznej. Prawie połowa badanych uznała swoją sytuację za dobra, niemal co czwarty za bardzo dobrą lub średnią. Tylko niewiele ponad 3\% respondentów wybrało opcje odpowiedzi: „zła” lub „bardzo zła”. Co ciekawe, jest to dwa razy mniej niż osób bezrobotnych, a więc osób teoretycznie w najgorszej sytuacji finansowej.

Podsumowując wyniki tzw. metryczki można pokusić się o nakreślenie sylwetki typowego turysty odwiedzającego Pojezierze Gostynińskie. Statystycznie jest to kobieta lub mężczyzna, osoba w młodym wieku: 20- lub 30-letnia, z wykształceniem co najmniej średnim, aktywna zawodowo lub studiująca, określająca swoją sytuację ekonomiczną najczęściej jako dobrą.

\subsection{Pochodzenie turystów}

Zasięg przestrzenny ruchu turystycznego na terenie Nadwiślańskiego Pogranicza Kujawsko-Mazowieckiego został określony za pomocą dwóch metod: informacji o pochodzeniu turystów uzyskanych podczas bezpośrednich wywiadów z nimi oraz identyfikacji numerów rejestracyjnych pojazdów parkujących w pobliżu wybranych atrakcji turystycznych regionu. Obie metody doprowadziły do podobnych wniosków.

Na podstawie wyników badań ankietowych ruch turystyczny na Pojezierzu Gostynińskim należy określić jako silnie lokalny. Jest to obszar wypoczynku przede wszystkim dla samych jego mieszkańców. Co trzeci ankie- 
towany pochodził z powiatu gostynińskiego, ponad 40\% z Płocka i powiatu płockiego, niemal co dziesiąty z powiatu kutnowskiego. Łącznie na te cztery sąsiadujące ze sobą powiaty przypada ponad $80 \%$ respondentów! Dodatkowo występuje przy tym duża koncentracja pochodzenia turystów w obrębie samego regionu. Najliczniej reprezentowane były największe miasta obszaru: Gostynin (25,8\%), Płock (15,9\%), Kutno (6,8\%) i Gąbin (6,2\%). Z innych miejscowości warto jeszcze wymienić: Łąck, Nowy Duninów (pow. płocki) oraz Kowal (pow. włocławski).

Istotne znaczenie jako centra generujące ruch turystyczny miały poza tym duże miasta (aglomeracje) położone na obrzeżach badanego regionu i poza nim: Włocławek i okolice, Warszawa, Łódź ze Zgierzem. Udział turystów z tych ośrodków sięgał 4-5\%. Liczba przybyszów z innych powiatów była już nieznaczna i wynosiła co najwyżej po kilka osób. Warto może tylko odnotować najbardziej odległe miejsca, z których turyści dotarli na Pojezierze Gostynińskie. Były to: Frącki (pow. olsztyński) oraz Gdańsk, Wrocław i Radom. W trójkącie, którego wierzchołki wyznaczają trzy ostatnie miasta, mieszkali praktycznie wszyscy ankietowani (rys. 4).

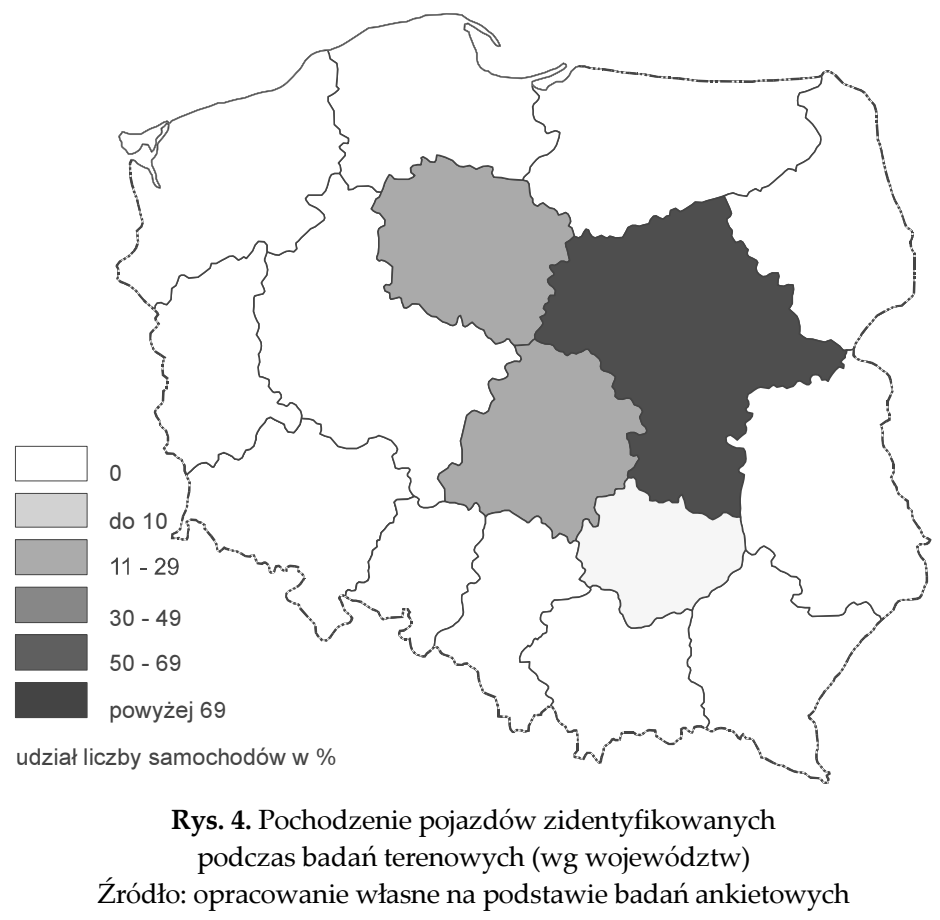


Podobne wyniki uzyskano podczas ewidencji tablic rejestracyjnych pojazdów parkujących na parkingach w pobliżu wytypowanych atrakcji turystycznych. Ogółem udało się zidentyfikować 1355 numerów, tj. niemal dwa razy więcej niż przeprowadzonych ankiet. Przygniatająca większość pojazdów $(71 \%)$ pochodziła z województwa mazowieckiego. Dwa dalsze województwa: kujawsko-pomorskie i łódzkie reprezentowane były po około $14 \%$ samochodów. Pięć aut zarejestrowano w Wielkopolsce, a po jednym na Podlasiu i w Świętokrzyskiem (rys. 4, tab. 1). Taki rozkład przestrzenny pochodzenia aut potwierdza transgraniczny charakter badanego regionu, na styku trzech województw.

Tablice rejestracyjne pojazdów pozwalają zidentyfikować nie tylko województwo, ale również i powiat, z którego pochodzi samochód ${ }^{9}$. Uzyskane w ten sposób wyniki są niemal takie same jak w przypadku badań ankietowych. Udział procentowy powiatu gostynińskiego jest jednak jeszcze większy (43\% wobec 30,6\%), podobnie jak powiatu włocławskiego (10,8\% wobec 2,6\%). Zmalał natomiast odsetek reprezentantów dużych miast (np. Łodzi i Warszawy). Zdaje się to potwierdzać tezę, że mieszkańcy innych regionów Polski, np. odwiedzający w regionie rodzinę, w celu penetracji okolicy przesiadają się do samochodu miejscowego kierowcy.

\subsection{Przyjazdy na Pojezierze Gostynińskie}

Dominującym środkiem komunikacji umożliwiającym turystom przybycie na Pojezierze Gostynińskie jest własny samochód. W ten sposób dotarło tu blisko 88\% ankietowanych. Na drugim miejscu znalazł się „rower” (5,51\% wskazań). Praktycznie żadnej roli w przyjazdach do regionu nie odgrywa transport publiczny. Ankieterzy nie spotkali żadnego turysty, który korzystałby z pociągu (PKP). Liczba klientów PKS wyniosła zaś zaledwie kilkanaście osób (ok. 2\%). Na słabą dostępność komunikacyjną regionu ankietowani zwracali zresztą uwagę również w innych punktach ankiety.

\footnotetext{
${ }^{9}$ Spisując numery tablic samochodowych uzyskujemy informacje o miejscu zarejestrowania pojazdu, a nie miejscu zamieszkania jego właściciela i/lub pasażerów. Dane te mogą się znacząco różnić, np. w przypadku korzystania ze służbowego auta lub zwiedzania okolicy samochodem osób mieszkających na danym terenie. Niekiedy występują również nietypowe (przydzielane na specjalne życzenie) numery rejestracyjne. Identyfikacja pochodzenia takiego auta nie jest wtedy w ogóle możliwa. Poza tym ewidencja pojazdów nic nie mówi o liczbie osób nimi podróżujących. Tym niemniej obie metody (ankietowa i spis rejestracji) doskonale się uzupełniają i pozwalają „uszczelnić” pomiar ruchu turystycznego.
} 
Tylko nieliczni respondenci przyjechali na Pojezierze Gostynińskie po raz pierwszy (niecałe 6\%). Dla większości był to już kolejny pobyt. Mniej więcej co dziesiąty badany przyznał, że jest to jego druga lub trzecia wizyta. Dominowali jednak stali bywalcy regionu. Dla prawie $3 / 4$ ankietowanych był to już co najmniej czwarty pobyt na tym terenie (wiele osób nie było nawet w stanie określić liczby dotychczasowych wizyt).

Grono stałych, wiernych bywalców składa się z dwóch podstawowych grup: tych, którzy wypoczywają na Pojezierzu Gostynińskim regularnie i bardzo często (z reguły 2-4 razy w miesiącu - niemal 35\% badanych) oraz tych, którzy przyjeżdżają regularnie, ale zdecydowanie rzadziej (co najmniej raz w roku - około $25 \%$ ). W obu przypadkach są to jednak przede wszystkim mieszkańcy regionu.

\subsection{Charakterystyka pobytów}

Pojezierze Gostynińskie jest obszarem krótkotrwałego wypoczynku. Ponad $64 \%$ respondentów przyznało, że spędza tu co najwyżej jeden dzień, przy czym $2 / 3$ z nich twierdziło, że ich pobyt na tym terenie ogranicza się zaledwie do kilku godzin ${ }^{10}$. Jeden nocleg na badanym obszarze deklarował co dziesiąty ankietowany, a tylko co czwarty pozostawał tu dłużej (w tym: na dwie noce $-9,4 \%$, na trzy noce $-6,4 \%$, na cztery i pięć nocy - po około $2,5 \%$ ).

Wyniki te mogą być jednak mylące. Ankiety przeprowadzane bowiem były w sezonie wakacyjnym, kiedy pojawiają się dłuższe pobyty stacjonarne. Dane statystyczne gestorów bazy noclegowej, które obejmują cały rok, dają trochę inny obraz. Średnia liczba noclegów przypadająca na jednego turystę w 2010 r. wyniosła 1,4. Zauważalny jest jednak trend malejący - w 2009 r. było to 1,67 noclegu/turystę, w 2008 r. zaś - 1,69 noclegu/turystę.

Spośród 690 respondentów tylko 14 osób przybyło na Pojezierze Gostynińskie w ramach wyjazdów zorganizowanych przez różne instytucje (zakłady pracy, organizacje społeczne, szkoły). Przygniatająca większość przyjazdów (98\%) miała charakter indywidualny i była organizowana we własnym zakresie: czy to przez samych turystów (72\%), czy też przez ich rodziny lub znajomych (26\%). Taki sposób przygotowywania podróży jest ściśle powiązany z charakterem pobytu. Tylko co dziesiąty badany przebywał w regionie

${ }^{10}$ Według nomenklatury UNWTO są to więc odwiedzający jednodniowi. 
samotnie, większość wypoczywała w towarzystwie znajomych $(48,1 \%)$, partnera $(27,7 \%)$ czy rodziny $(22,5 \%)^{11}$.

Turyści, zapytani o cel przyjazdu na Pojezierze Gostynińskie, mogli wskazać kilka odpowiedzi spośród kilkunastu zaproponowanych opcji (rys. 5). Respondenci zgodnie jednak wybierali „wypoczynek” (niemal 85\% ankietowanych). Drugą pod względem popularności odpowiedzią było poznanie walorów przyrodniczych regionu (21,9\%). Dla co dziewiątego badanego pretekstem do przyjazdu w te strony było wydarzenie rodzinne. Zaskakujący może być dość niski odsetek wskazań na turystykę aktywną (4,6\%). Wymieniano tu m.in. jazdę rowerem, pływanie, grzybobranie, jazdę konna, sporty wodne, wędkarstwo, nordic walking. Wydaje się jednak, że są to odpowiedzi dotyczące wyłącznie głównego celu przyjazdu. Podobne aktywności, ale podejmowane dodatkowo, mieszczą się w pojęciu „wypoczynek”.

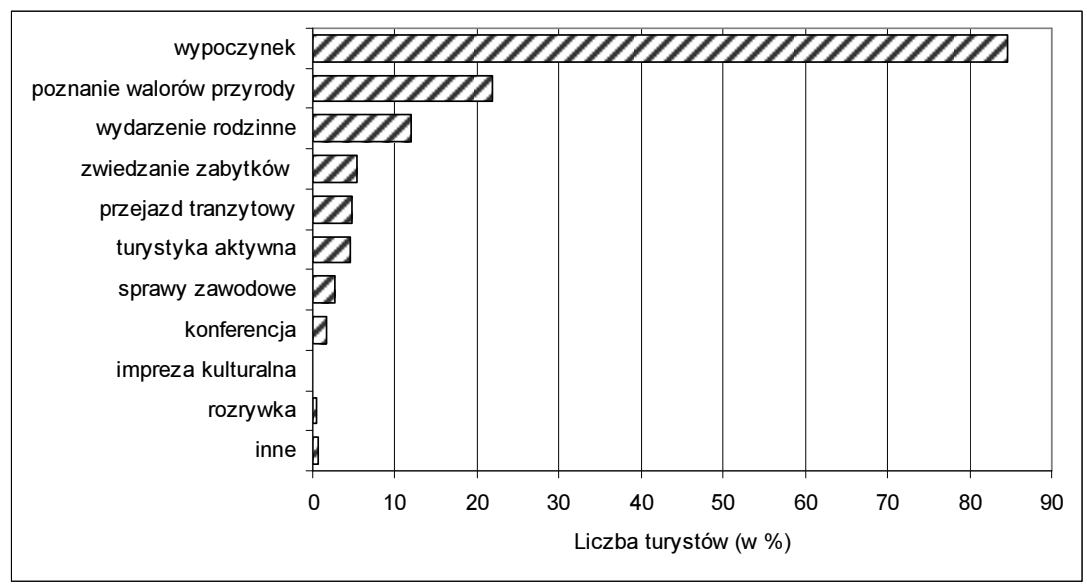

Rys. 5. Cel przyjazdu na Pojezierze Gostynińskie

Źródło: opracowanie własne na podstawie badań ankietowych

Kolejne pytanie ankiety miało na celu identyfikację sposobu spędzania czasu przez turystów przebywających na Pojezierzu Gostynińskim. Również w tym przypadku ankietowani mogli podać kilka wariantów odpowiedzi (rys. 6). Dominującą formą rekreacji okazał się bierny wypoczynek na plaży (ponad $77 \%$ badanych) uzupełniany spacerami $(36,2 \%)$ oraz spotkaniami ze dziny.

${ }^{11}$ Wartości nie sumują się do 100\%, gdyż zdarzały się wyjazdy „mieszane”: w gronie znajomych i ro- 
znajomymi (31,1\%). Zdecydowanie rzadziej podejmowano piesze wycieczki $(13,8 \%)$ i zwiedzanie $(9,1 \%)$. Dla $11 \%$ respondentów ważne były wizyty w klubach i dyskotekach. Spośród form turystyki aktywnej i specjalistycznej najczęściej wymieniano: wędkarstwo (11\%), grzybobranie $(8,8 \%)$, wycieczki rowerowe (5,9\%) i jazdę konno (2,6\%).

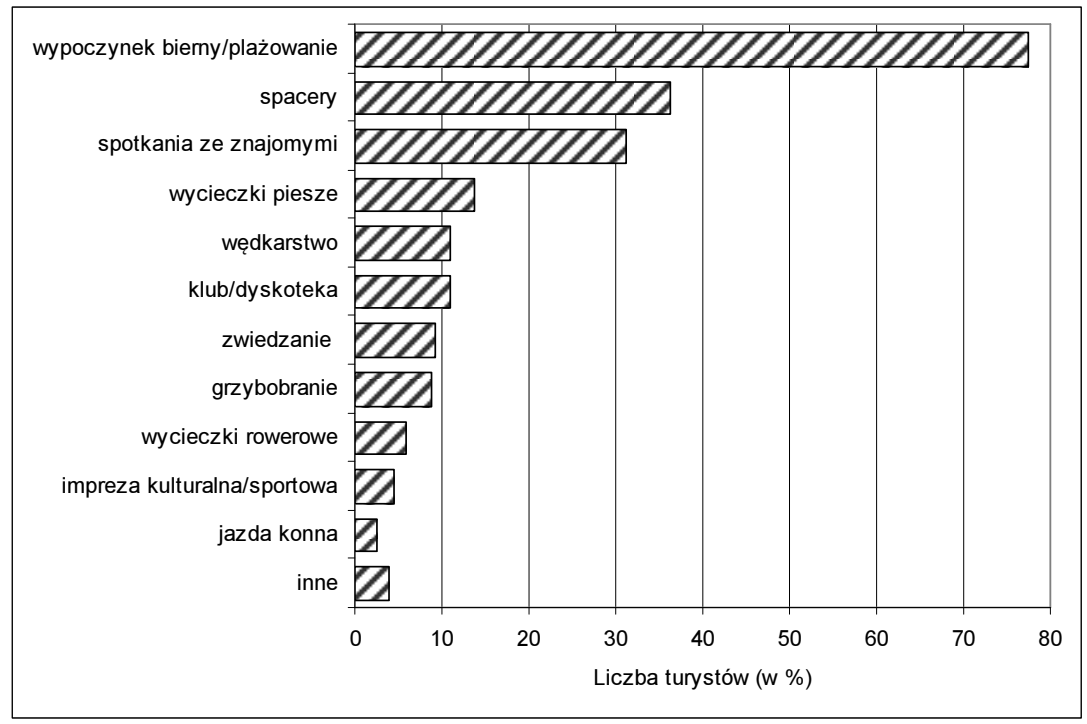

Rys. 6. Formy rekreacji podczas pobytu na Pojezierzu Gostynińskim Źródło: opracowanie własne na podstawie badań ankietowych

Badani turyści stosunkowo rzadko korzystali z oferty turystycznej, wybierając tylko nieliczne, niezbędne usługi (rys. 7). Najwięcej ankietowanych (77,4\%) wybrało kąpieliska i plaże, co z uwagi na wypoczynkowy charakter większości pobytów nie powinno dziwić. Ale już tylko niewiele ponad 50\% respondentów skorzystało z usług gastronomicznych. Można więc przypuszczać, że druga połowa turystów żywiła się we własnym zakresie. Jeszcze mniej badanych $(45,5 \%)$ miało kontakt z bazą noclegową. Większość przyjezdnych spędzała noc we własnym domu lub u rodziny. Z usług dodatkowych największą popularnością cieszyły się wypożyczalnie sprzętu wodnego (ponad 30\%). Szlaki turystyczne odwiedziło niespełna 13\% ankietowanych. Swoich amatorów miały też dyskoteki (10\%) i wypożyczalnie rowerów $(5,8 \%)$. Pozostałe elementy oferty nie wzbudzały już większego zainteresowania turystów. 
Dla blisko 55\% badanych bazą wypadową do penetracji turystycznej obszaru był własny dom. Wynika to $\mathrm{z}$ dominującej $\mathrm{w}$ regionie formy jednodniowych przyjazdów wypoczynkowych. Pozostali turyści wybierali na nocleg różne obiekty hotelarskie, głównie te o niższym standardzie. Największą popularnością cieszyły się kempingi i pola namiotowe (23,8\%). Zdecydowanie mniejsza liczba gości zatrzymała się w ośrodkach wczasowych $(7,5 \%)$ i gospodarstwach agroturystycznych $(5,7 \%)$. Tylko $4,4 \%$ respondentów wybrało hotel.

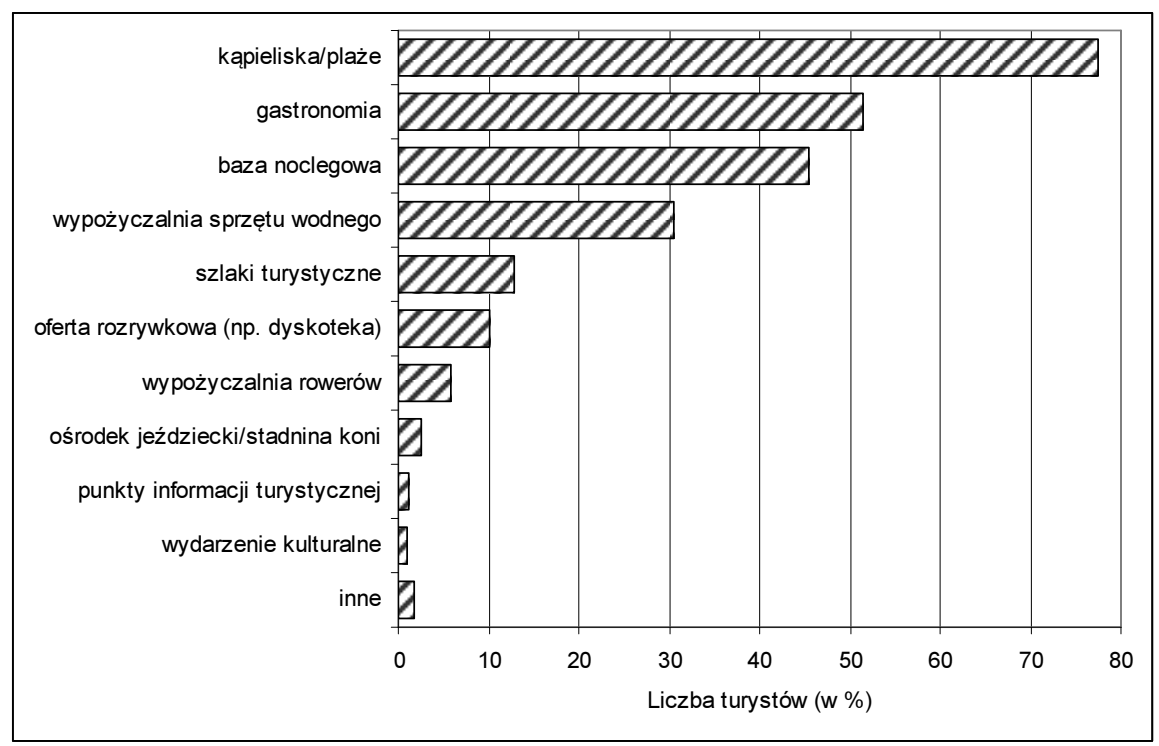

Rys. 7. Korzystanie z oferty turystycznej regionu

Źródło: opracowanie własne na podstawie badań ankietowych

Rozkład miejsc odwiedzonych przez ankietowanych podczas ich wypoczynku na Pojezierzu Gostynińskim nie jest zaskakujący. Generalnie ruch turystyczny rozproszony jest po całym regionie, jednak z wyraźną koncentracją wokół najbardziej atrakcyjnych jezior. Ewidentnie zaznacza się przy tym przewaga zespołu jezior Białego i Sumino, które skupiły niemal 18\% badanych. Mniejszą popularnością cieszyły się jeziora: Lucieńskie (10,4\%), Górskie i Ciechomickie (prawie 10\%), a także Skrzyneckie (8,7\%) i Zdworskie (ponad 6\%). Akweny mniejsze oraz położone na obrzeżach 
obszaru badań odwiedzane były zdecydowanie rzadziej (Soczewka $-3,3 \%$, Rakutowskie i Lubiechowskie - 0,7\%, Przytomne - 0,1\%).

Respondenci często podawali nie tylko nazwę jeziora, ale również miejscowości, w której byli lub aktualnie wypoczywają. Wśród najczęściej wymienianych lokalnych „kurortów” znalazły się: Miałkówek (8,3\% wskazań), Grabina (7,4\%, w równej mierze ze względu na plażę, jak i dyskoteki), Nowy Duninów $(4,2 \%$, tu rolę dodatkowego magnesu przyciągającego turystów odgrywały regaty żeglarskie), Zdwórz (3,2\%) i Skrzynki (3\%).

W świetle wyników badań za główne centrum krajoznawcze Nadwiślańskiego Pogranicza Mazowiecko-Kujawskiego należy uznać położony już poza jego granicami Płock, który odwiedził co dziesiąty ankietowany. Istotną rolę w turystyce poznawczej odgrywają również Gostynin (niemal 6\%, obok zabytków miasta często wymieniano także oz „Dybankę") i Łąck (niemal 6\%, tu główną atrakcją była stadnina koni), zdecydowanie mniejszą - Gąbin (1,7\%). Pozostałe miejscowości, zarówno na badanym terenie, jak i w jego najbliższym otoczeniu, odwiedzane były już sporadycznie, przez nielicznych turystów.

Trzeba jednak mieć świadomość, że na uzyskane wyniki w pewnym stopniu wpłynęły miejsca prowadzenia badań. Wynika to z faktu, że przeważająca część przyjazdów na Pojezierze Gostynińskie trwa dosłownie kilka godzin i ogranicza się jedynie do pobytu w jednym miejscu, ewentualnie odwiedzeniu 2-3 miejscowości po drodze z i do domu. Potwierdzają to wyniki pytania o miejsca planowane do odwiedzenia. Ponad połowa ankietowanych (53\%) nie miała takich planów! Pozostali zamierzali jeszcze odwiedzić inne jeziora pojezierza (przede wszystkim: Skrzyneckie, Białe i Sumino, Zdworskie oraz Lubieńskie) lub zabytkowe miasta: Płock (4,6\%), Gostynin $(4,5 \%)$, Włocławek (3,8\%). Zauważalne zainteresowanie respondentów wzbudzała też stadnina koni w Łącku (2,9\%).

Z punktu widzenia lokalnej gospodarki jednym z ważniejszych wskaźników ekonomicznych rozwoju turystyki są ogólne wydatki odwiedzających (często w przeliczeniu na osobę lub osobodzień). Wydatki turystów na terenie Nadwiślańskiego Pogranicza Mazowiecko-Kujawskiego pozostają na stosunkowo niskim poziomie. Prawie połowa ankietowanych wydała mniej niż 100 zł na osobę, kolejne 20\% - 100-200 zł/os., a co dziesiąty - 200-300 zł/ os. Przeciętne wydatki można szacować na 130-177 zł/os.

Przyczyny takiego rozkładu wydatków są złożone, ale z pewnością istotną rolę odgrywa tu m.in.: organizacja wyjazdów głównie we własnym za- 
kresie, przewaga krótkich, kilkugodzinnych pobytów (bez noclegu), nastawienie większości turystów na bierny wypoczynek, wreszcie dość skromna oferta regionu (zarówno pod względem zakresu, jak i standardu usług).

\subsection{Opinie turystów}

W końcowej części ankiety poproszono respondentów o ocenę oferty turystycznej Pojezierza Gostynińskiego. Badani mieli wskazać najmocniejsze strony (atuty) regionu, elementy, które wymagają udoskonalenia, a także zupełnie nowe elementy, które powinny zostać wprowadzone w najbliższym czasie. Były to pytania otwarte - ankietowanym nie sugerowano żadnych wariantów odpowiedzi, mogli też podać ich dowolną liczbę.

Za największy atut Pojezierza Gostynińskiego badani turyści uznali walory naturalne. Niemal połowa respondentów (47\%) uznała je za wyjątkowe, choć oczywiście wymieniano różne składniki środowiska przyrodniczego. Co czwartemu ankietowanemu najbardziej podobała się duża ilość lasów i jezior. Podkreślano również: „piękne krajobrazy (panoramy)”, ciszę i spokój, a także czyste, nieskażone środowisko (powietrze, lasy, wody). Za szczególnie ważny walor wypoczynkowy regionu uznawano dużą liczbę plaż.

Drugą grupę atutów Nadwiślańskiego Pogranicza Mazowiecko-Kujawskiego stanowi zagospodarowanie turystyczne (wskazało je 16,7\% badanych). Odpowiedzi rozłożyły się stosunkowo równomiernie pomiędzy: bazę noclegową (podkreślano jednak nie standard obiektów hotelarskich, ale ich położenie bezpośrednio nad jeziorami), szlaki turystyczne i ścieżki rowerowe, atrakcje dla dzieci (place zabaw) oraz wypożyczalnie sprzętu wodnego.

Dla co dziesiątego respondenta ważna okazała się dogodna lokalizacja regionu wypoczynku. Za taką uważano zarówno bliskość w stosunku do miejsca zamieszkania, jak i łatwy dostęp do jezior, lasów i Wisły. Zbliżony odsetek turystów $(8,1 \%)$ cenił sobie sprzyjające warunki wypoczynku na Pojezierzu Gostynińskim. Podkreślano zwłaszcza, że jest to obszar nie zawładnięty jeszcze przez masową turystykę i że wypoczywający mają do swej dyspozycji duże bezludne tereny. Równie ważne okazały się szerokie możliwości uprawiania różnych form aktywnego wypoczynku: wędkarstwa, pływania na rowerach wodnych, jazdy konnej, jazdy na rowerach, zbierania grzybów itd. 
Obok atutów Pojezierza Gostynińskiego, ankietowani zauważyli też wiele niedociągnięć i uchybień, które negatywnie wpływają na wypoczynek. Do największych minusów zaliczono przede wszystkim nie najlepszy stan infrastruktury turystycznej (21,1\% wskazań). W opinii badanych modernizacji wymaga zarówno baza noclegowa (konieczne są remonty domków letniskowych, budowa węzłów we wszystkich domkach i pokojach), jak i gastronomiczna (dotyczy to restauracji i zwykłych punktów gastronomicznych). Dużo respondentów (9,9\%) domagało się też poprawy zagospodarowania plaż. Istotny problem dla wielu turystów stanowi również niezadowalający stan czystości regionu (zaśmiecone plaże, jeziora i lasy, ubogie zaplecze higieniczno-sanitarne, brak koszy na śmieci) i jego słaba dostępność komunikacyjna (ogólnie zły stan techniczny dróg, brak dróg dojazdowych do jezior, brak parkingów przy hotelach i plażach, nieliczne publiczne środki transportu).

Z elementami oferty turystycznej wymagającymi poprawy korespondują propozycje wprowadzenia zupełnie nowych składników produktu turystycznego obszaru. Najwięcej postulatów dotyczyło rozwoju i unowocześnienia infrastruktury turystycznej (ogółem 19\%), w tym lepszego zagospodarowania już istniejących plaż, doposażenia wypożyczalni w nowoczesny sprzęt wodny, budowy nowych atrakcji plażowych (np. zjeżdżalni). Badani dość zgodnie wskazywali na konieczność rozwoju bazy noclegowej, bazy gastronomicznej (więcej lokali o wyższym standardzie: barów i restauracji) oraz bazy rekreacyjno-rozrywkowej (nowe dyskoteki i kluby). Postulowano też stworzenie zupełnie nowych atrakcji dla turystów, np. masowych imprez plenerowych (kulturalnych i sportowych), a także umożliwienie uprawiania sportów ekstremalnych (w tym zwłaszcza jazdy na quadach).

W opinii ankietowanych niezbędne jest też zwrócenie baczniejszej uwagi na bezpieczeństwo i porządek w regionie. Dotyczy to głównie zapewnienia bezpieczeństwa kąpiącym się w jeziorach (organizacja strzeżonych plaż z ratownikami), a także zwiększenia liczby patroli policji oraz zaostrzenia systemu zakazów i kar.

Syntetycznym wskaźnikiem zadowolenia turystów z wypoczynku w danym miejscu jest chęć powrotu do niego w przyszłości oraz chęć rekomendacji go wśród rodziny i znajomych. Ponowne odwiedziny Pojezierza Gostynińskiego zadeklarowało niemal 89\% zapytanych (ponad 50\% - zdecydowanie tak, 38\% - raczej tak). Osób, które twierdziły, że nie przyjadą tu więcej było zaledwie kilkanaście. Grupa niezdecydowanych liczyła 8,4\% (rys. 8). 
Wyraźnie słabiej wypadła chęć rekomendacji regionu. Odsetek tych, którzy będą zachęcać do przyjazdu w region Nadwiślańskiego Pogranicza Mazowiecko-Kujawskiego spadł o 12\% (do poziomu 77\%, w tym tylko 40,5\% twierdzi, że „na pewno tak”). Udział osób, które nie będą polecały wypoczynku na pojezierzu sięgnął ponad $6 \%$, a odsetek respondentów niemających zdania na ten temat wzrósł dwukrotnie.

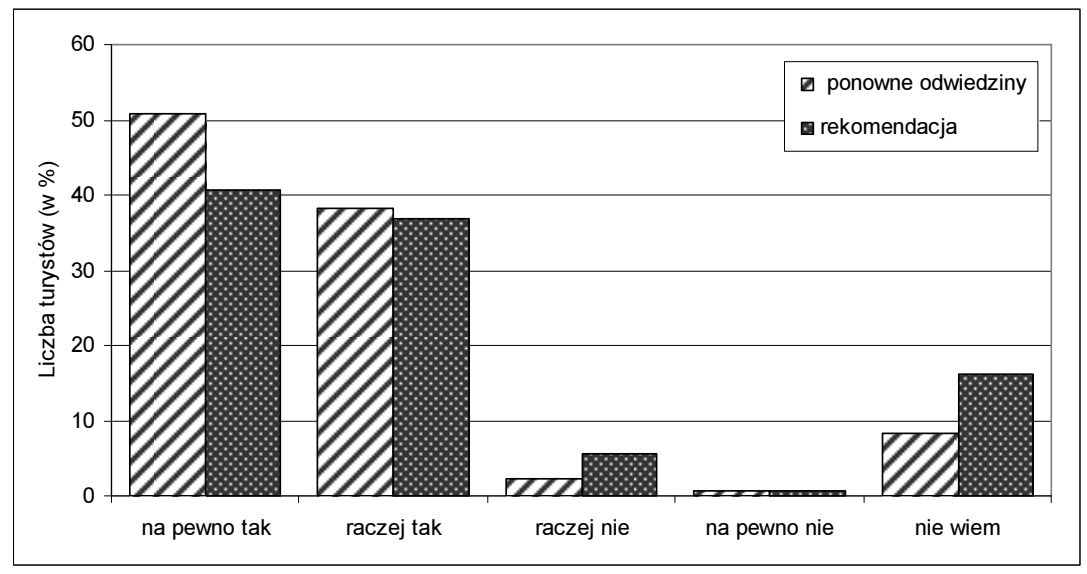

Rys. 8. Ponowne odwiedziny i rekomendacje Pojezierza Gostynińskiego Źródło: opracowanie własne na podstawie badań ankietowych

Większość ankietowanych doskonale wie, że choć oferta turystyczna regionu ma sporo niedostatków, to z uwagi na bliskość miejsca zamieszkania czy sytuację materialną nie ma realnej alternatywy lepszego miejsca wypoczynku (zwłaszcza krótkotrwałego) i z pewnością na teren Pojezierza Gostynińskiego jeszcze nie raz wróci. Mając jednak świadomość słabych stron tego obszaru, polecaliby go innym turystom z pewną rezerwą i ostrożnością.

\section{Podsumowanie}

Po 1989 r. w wielu miejscowościach i regionach w Polsce nastąpił dynamiczny rozwój turystyki, w wielu innych jednak - mimo długoletnich tradycji wypoczynku, a także usilnych starań władz samorządowych i lokalnych przedsiębiorców - obserwuje się wyraźną stagnację, a nawet regres ruchu 
turystycznego. Do tej drugiej grupy wypada zaliczyć teren Nadwiślańskiego Pogranicza Mazowiecko-Kujawskiego. Obszar ten już od pół wieku pełni funkcje turystyczne, ale obecnie „zamarł” w oczekiwaniu na rozwój nowych form turystyki. Powstanie nowoczesnego kompleksu rekreacyjno-balneologicznego "termy gostynińskie" miało stać się potężnym impulsem do skokowego wzrostu ruchu turystycznego w promieniu $20-25 \mathrm{~km}$ od miasta. Z różnych powodów tak się na razie nie stało. Wobec braku innych koncepcji rozwoju sektora turystycznego rejon bazuje na razie na dotychczasowych, „starych" formach ruchu turystycznego.

Przeprowadzone badania dowiodły, że na Pojezierzu Gostynińskim wypoczywają przede wszystkim sami mieszkańcy regionu (z niewielkim udziałem mieszkańców aglomeracji warszawskiej i łódzkiej). Wypoczynek ma charakter wysoce sezonowy. Dominują krótkotrwałe pobyty, podczas których przyjezdni w prosty sposób wykorzystują oczywiste walory przyrodnicze obszaru (kąpiel w jeziorach, spacery po lesie, łowienie ryb, zbieranie grzybów itp.), stosunkowo rzadko korzystając z dostępnych usług. Mimo pojawienia się $\mathrm{w}$ ostatnich latach nowych form turystyki aktywnej, ekoi agroturystyki, oferta turystyczna regionu pozostaje raczej uboga i mało atrakcyjna (dotyczy to zwłaszcza w większości już przestarzałej infrastruktury turystycznej). Na niską konkurencyjność obszaru zgodnie zresztą wskazywali i turyści, i gestorzy bazy noclegowej. Nic więc dziwnego, że zarówno liczba wypoczywających, jak i długość pobytów na Pojezierzu Gostynińskim wykazują systematyczną tendencję spadkową.

Niniejsze opracowanie podsumowuje pierwszy sezon badawczy na terenie Nadwiślańskiego Pogranicza Mazowiecko-Kujawskiego. Aby móc z całą stanowczością określić rysujące się tendencje i prawidłowości, a także prognozować rozwój ruchu turystycznego w przyszłości, konieczne są dalsze cykliczne badania, przy jednoczesnym doskonaleniu metodyki zbierania informacji i dostosowywania jej do specyfiki terenu. Tym niemniej opracowany materiał z całą pewnością jest dobrym punktem wyjścia do szerszej dyskusji nad aktualną ofertą turystyczną regionu. Zawarte $\mathrm{w}$ nim dane i wnioski powinny być przydatne zarówno dla przedsiębiorców w ich codziennym zarządzaniu swoimi firmami, jak i dla decydentów odpowiedzialnych za rozwój turystyki na tym terenie. W przypadku fiaska projektu „termy gostynińskie" niezbędne bowiem będzie podjęcie skutecznych działań modernizacyjnych lub opracowanie zupełnie nowych, alternatywnych kierunków rozwoju. 


\section{BIBLIOGRAFIA}

Badanie ruchu turystycznego na terenie Nadwiślańskiego Pogranicza Mazowiecko-Kujawskiego - lato 2011, Raport końcowy, opr. J. Grabowski, A. Stasiak, Wyższa Szkoła Turystyki i Hotelarstwa w Łodzi, Fundacja „Aktywni Razem”, Łódź - Łąck 2012.

Definicje podstawowych pojęć z zakresu turystyki, 1979, „Zeszyty Metodyczne” 30, GUS, Warszawa.

KONDRACKI J., 2002, Geografia regionalna Polski, PWN, Warszawa.

Lokalna strategia rozwoju Nadwiślańskiego Pogranicza Mazowiecko-Kujawskiego. Dokument programowy Fundacji "Aktywni Razem", 2011, Środowisko s.c., Łąck, listopad 2008 (aktualizacja: styczeń 2011), dokument dostępny w wersji elektronicznej: http://www.aktywnirazem. pl/pliki/file/STRATEGIA\%2026_07_2012.pdf.

Zintegrowana strategia rozwoju obszarów wiejskich regionu gąbińsko-włocławskiego, 2006, Środowisko s.c., dokument dostępny w wersji elektronicznej: http://www.pojezierzegostyninskie. pl/index.php?p=43. 